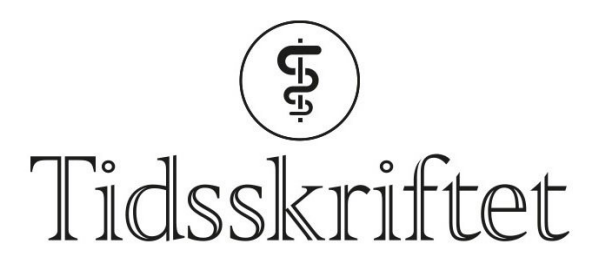

DEN NORSKE LEGEFORENING

\title{
Syke mennesker
}

MINILEDER

\section{ARE BREAN}

Sjefredaktør

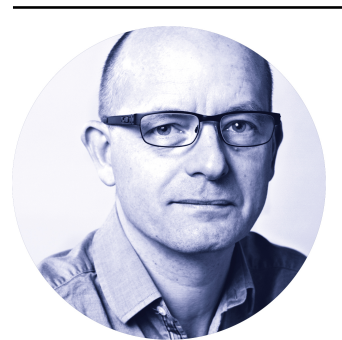

Føler du deg frisk? Vel, statistikken er ikke på din side lenger. 63\% av alle over 45 års alder trenger behandling for hypertensiv sykdom, dersom American College of Cardiology og American Heart Associations nye definisjon av hypertensjon anvendes på den amerikanske befolkningen. Det viser en ny studie publisert i BMJ. Den samme studien fastslår at mer enn halvparten av dem som allerede får medikamenter for hypertensjon ifølge kriteriene er underbehandlet og trenger enda flere medikamenter. Det er liten grunn til å tro at tallene er svært annerledes i Norge.

Når vi holder oss med diagnosekriterier som gjør halvparten av den voksne befolkningen til behandlingskrevende pasienter, er det grunn for oss leger til å stoppe opp og løfte blikket fra reseptblokken. Flere diagnoser, flere piller og flere legekontroller er ikke det som skal til for å bedre folkehelsen. Mest medisin er sjelden best medisin.

Publisert:3. september 2018. Tidsskr Nor Legeforen. DOI: 10.4045/tidsskr.18.13.01

(C) Tidsskrift for Den norske legeforening 2020. Lastet ned fra tidsskriftet.no 